\title{
Responsible research and innovation as a travesty of technology assessment?
}

\author{
Pierre Delvenne \\ SPIRAL Research Centre, University of Liège, Liège, Belgium
}

\section{ABSTRACT}

The relation between technology assessment (TA) and responsible research and innovation (RRI) is a very topical (and controversial) issue, as TA is clearly enveloped in broader science, technology and innovation (STI) processes, such as the EU-wide shift towards RRI. In this short response to van Lente et al.'s essay, I first stress that this contribution has several merits; for example, it points to pervasive challenges for TA communities, such as the issue of including normative concerns when assessing innovations, it opens these challenges to debate, without shying away from engaging TA communities. However, I disagree with the authors' claim that RRI would be 'a next step of TA' or even a 'form of TA'. In my essay, I explain why I believe RRI is different from TA and why, rather than a critique of TA, RRI could instead lead to a travesty of TA, threatening the vitality and the uniqueness of TA institutions in the long-term. Under the spell of RRI, TA risks being reduced to a role of mere provider of ex-ante impact assessments. I conclude that following the money attached to RRI has a price that TA institutions should carefully, critically and reflexively consider before they pay.
ARTICLE HISTORY

Received 1May 2017

Accepted 2 May 2017

\section{KEYWORDS}

Technology assessment; responsible research and innovation; politics of TA

In the early nineteenth century, the English author Mary Shelley published a novel entitled 'Frankenstein; or, the Modern Prometheus' that tells the story of Victor Frankenstein, a young scientist who creates a grotesque but intelligent monster in a scientific experiment. Two centuries later, both the nature and the space of experiments have changed drastically. While experiments are still generally thought of as actions or operations undertaken to test a scientific hypothesis in settings detached from the rest of society (e.g. in scientific laboratories), I suggest situating responsible research and innovation (RRI) in a more macro-sociological understanding of 'experiment', one that implies a process of societal self-experimentation (Gross and Krohn 2005), and with social scientists and technology assessment (TA) practitioners partaking in the experiment as observing participants. ${ }^{1}$ RRI's origins are often attributed to René Von Schomberg, ${ }^{2}$ a Dutch philosopher with a background in science and technology studies (STS) and TA. Rather than in a scientific lab, it is from within the European Commission that Von Schomberg imagined the world of RRI (2011a, 2011b). Like a modern Victor Frankenstein, the inventor now has to follow his conceptual creature and to face its intended and unintended consequences,

CONTACT Pierre Delvenne pierre.delvenne@ulg.ac.be

๑ 2017 Informa UK Limited, trading as Taylor \& Francis Group 
from the corridors of the European Commission to the venue of academic conferences, to articles published in academic journals like the highly acclaimed academic Journal of Responsible Innovation (JRI). Interestingly, both as a concept and as an approach, even though it has now become an overarching key feature of the EU Horizon 2020 Programme, RRI is still characterized by uncertainty and open-endedness. It is still 'very AQ4 much a policy innovation project in the making, its boundaries are not yet determined or fixed; rather, they are continuously expanded and redrawn' (Van Oudheusden 2014, 2). It is also a label 'that may intuitively feel right, but which exhibits a lack of clarity in terms of definition, practice and, at a policy level, motivation' (Owen, Macnaghten, and Stilgoe 2012, 752).

In spite of its indistinctness, RRI's 'impressive' 'career through the realms of national and European policy' (Van Lente, Swierstra, and Joly 2017) and in academia deserves due attention, especially when it meets older traditions, philosophies and practices purportedly in line with its rationale. It is at the occasion of one of RRI's encounters with TA that I am given the opportunity of writing this short response to Harro van Lente, Tsjalling Swiestra and Pierre-Benoît Joly's essay on 'Responsible Innovation as a critique of Technology Assessment'. Before I go any further, I believe it is relevant to mention that I was present at the second PACITA ${ }^{3}$ conference in Berlin (25-27 February 2015), where this paper was first presented and generated animated debates among panelists and other participants. During their talk, van Lente et al. quoted the PACITA manifesto (first publicly presented at the same conference), arguing that the TA community was diplomatically recalling its prominence and policy relevance as the 'self-appointed mother of RRI':

Responsible Research and Innovation has shaped the last year's policy discourse in Europe related to the societal role of research and innovation. It has given key concepts in TA, such as participation, forward-thinking, reflexivity and policy action, greater focus. TA can and should be a key carrier of the concept and play a light-house role in RRI. (PACITA manifesto)

In the discussion following the talk, both René Von Schomberg and several TA practitioners expressed their concerns that the authors had not properly understood the premises of either RRI or TA approaches, and they contested the idea of taking RRI as a critique of TA. As in numerous previous other occasions, Von Schomberg recited his renowned, and widely circulated, definition of RRI, almost as if it were sufficient to show the merits and imperious necessity of the approach:

Responsible Research and Innovation is a transparent, interactive process by which societal actors and innovators become mutually responsive to each other with a view to the (ethical) acceptability, sustainability and societal desirability of the innovation process and its marketable products (in order to allow a proper embedding of scientific and technological advances in our society). (Von Schomberg 2011a, 9)

He stressed that TA was at the heart of the RRI approach, alongside technology foresight and impact assessment, and that the institutionalization of these prospective tools could 'help to identify societal desirable products by addressing the normative anchor points throughout their development' (see Von Schomberg 2011a, 10). In turn, TA practitioners were unhappy with van Lente et al.'s provocative formulation and they recalled the 
anteriority of TA approaches and practices, stressing that TA will continue to play a role in the development of RRI.

In other words, the relation between TA and RRI is a very topical (and controversial) issue, as TA is clearly enveloped in broader science, technology and innovation (STI) processes, such as the EU-wide shift towards RRI (Delvenne et al. 2015, 26). It is thus important that critical debates take place in academic settings (e.g. journals like JRI), in order to further progress the understanding and operationalization of both approaches and related practices. The essay of van Lente et al. has several merits; for example, it points to pervasive challenges for TA communities, such as the issue of including normative concerns when assessing innovations, it opens these challenges to debate, without shying away from engaging TA communities. However, the essay is less lively than the debate at the PACITA conference and, in my view, it fails to acknowledge the variety and richness of institutional TA models, methodologies and approaches that coexist today. To support their brief description of what TA is about, they narrowly focus on the US Office of Technology Assessment (OTA), which closed its doors more than twenty years ago and has never had an equivalent in Europe. In spite of numerous exchanges between OTA staffers and European delegations in the early days of European Parliamentary TA, it was never possible to duplicate the American OTA elsewhere. This was due to the presence of relatively weaker Parliaments in Europe, benefiting from limited in-house capacities and slimmer budgets than their American counterpart (Delvenne 2011, 26). While it is true that TA was originally developed within the context of US policy-making in the 1970s, TA practices quickly gained impetus in Europe, somewhat independently from what was happening in the US, notably through the erection of parliamentary TA (PTA) agencies on the EU level and on the national and regional levels of policy-making (Vig and Paschen 2000; Joss and Bellucci 2002; Delvenne 2011; Ganzevles, van Est, and Nentwich 2014).

Since then, governmental and nongovernmental entities, such as universities and think tanks, have also adopted the TA label, resulting in a variety of TA practices, including constructive TA (Rip, Misa, and Schot 1995; Schot and Rip 1997; see also Rip and van Lente 2013 on more recent CTA developments), interactive TA (Grin, Van de Graaf, and Hoppe 1997), real-time TA (Guston and Sarewitz 2002), policy-oriented TA (Klüver et al. 2016) and programs that bear a strong resemblance to TA, such as upstream public engagement in science and technology (Wilsdon, Stilgoe, and Wynne 2005) and, later on, RRI. Whereas the authors rightly point at the fact that the initial aim of TA was to reduce the costs of technologies' detrimental effects by anticipating potential impacts of technology and providing policymakers with ostensibly neutral scientific advice, TA subsequently became a process of ongoing dialogue that supports actors' decision-making processes and the formation of opinions on science-society issues. Generally speaking, the coexistence of various models and approaches from the outset, rather than the succession of TA generations (as argued by van Lente et al. but also by some members of the TA community, e.g. Van Eijndhoven 1997), has always reflected the need for TA institutions to fit with their national civic epistemologies (Jasanoff 2004), that is, 'styles of reasoning, modes of argumentation, standards of evidence, and norms of expertise that characterize public deliberation and political institutions' (Miller 2008, 1896). Thus, rather than having 'old TA' being overcome by the advent of 'new TA' or 'Constructive TA', different ways of doing TA developed concurrently. Even though not every PTA embraced the participatory turn in 
the exact same way, all PTA institutions were to some extent participatory, in the sense of including experts, stakeholders or citizens in the TA process (Joss 2000; Vig and Paschen 2000; Joss and Bellucci 2002; Delvenne 2011). Van Lente, Swierstra, and Joly (2017) also consider that Denmark and the Netherlands have been at the forefront of public participation in TA settings, which is true, but it is only a part of the story. They forget to mention that in these two countries as in many others across Europe, including but not limited to Switzerland, Norway, Belgium or Austria, numerous participatory methods relevant to emerging issues to be tackled were invented and deployed either at the regional, national, European or even global levels. ${ }^{4}$ Like many academics, although I admit this is also often heard in the TA world, the authors continue to refer to the famous consensus conference, first adapted by the Danes in the 1980s, as if it still were the hallmark of participatory TA. Doing so, they seem to ignore that, for fifteen years or so, even the Danes have stopped organizing costly consensus conferences. Instead, they usually give their preference to more affordable or simply different (combinations of) methods to reach out to the experts, stakeholders and citizens.

Furthermore, while it may be heuristically helpful to present TA rationales as if they were mutually exclusive, for instance expert and participatory/TA, in real-life settings it is extremely common to have experts, stakeholders and citizens consulted in one single project. In other words, even though I understand that their history of TA had to be brief, the authors provide us with an oversimplified and somehow misleading account of what TA actually is and has been about. Lastly, as regards the possible 'perversity' of what they label 'new TA', namely the risk of identifying with the particular interests of the stakeholders, I wonder why it wouldn't be a risk when consulting experts too (the so-called attribute of 'old TA'). Indeed, experts' particular interests, values, norms and worldviews are enmeshed with the social construction of science and technologies. Van Lente et al. emphasize the risk that identifying with particular interests would turn 'TA into politics by other means'. Keeping on with the provocative and constructive tone of my interlocutors, I claim the benefits of a certain perversity and, to paraphrase Winner (1980), I argue that TA has politics, and that this is a potentially good thing not to be ashamed or afraid of. Indeed, as we explain elsewhere (see Delvenne et al. 2015; Van Oudheusden et al. 2015) TA is typically associated with a political preference for more participatory or deliberative modes of decision-making, supporting the ideas of publics' 'empowerment', 'policy enlightenment', 'healthier aging' or 'sustainable development'. These preferences are not neutral. They have been reproduced in a great number of European countries where left-wing political parties play, or played, a key role in institutionalizing TA (Delvenne 2011). As Van Oudheusden (2014) notes, TA's political affiliations are often denied or downplayed across TA communities. TA is typically framed as an analytic activity aimed at providing decision-makers with an objective analysis of a technology (Van Eijndhoven 1997) and/or as an interactive and communicative tool that aims to enrich the basis for public debate and STI decision-making (Decker and Ladikas 2004, see also the EPTA website). These broad designations (i.e. geared towards all political factions and to the benefit of all innovation actors) risk trivializing and undermining the very policy changes TA advocates seek to instigate when TA is associated with specific political parties or politicians (Delvenne et al. 2015, 26). The claim of neutrality as a legitimatory myth' for TA has undoubtedly been helpful to anchor the approach in evidence-based modes of policy-making. However, the recent de-institutionalization processes in Flanders 
and Denmark may lead the TA communities to reassess the myth's usefulness and relevance. Reflecting on the closure of the Danish Board of Technology as a governmentfunded institution, Horst (2014) quoted famous lyrics by Cohen (1992):

Ring the bells that still can ring

Forget your perfect offering

There is a crack, a crack in everything

That's how the light gets in.

Today, TA communities themselves are looking through the cracks of parliamentary TA as-we-know-it and are beginning to wonder if it is still bearable and productive for TA to 'restrict itself to the role of a "knowledge broker" and refraining from taking a strong political stance in terms of recommending specific political action' (Hennen and Nierling 2017). My personal opinion is that TA should give up the chimera of neutrality and run the risk of facing the implications of taking sides in order to advance critical ideas and to deepen societal debates from the privileged position it enjoys at the intersection of STI, politics and society. Assuming its politics, 'partisan' TA should not be taken as political parties' research units, but it would for sure have immediate political relevance. If TA is not or cannot be a 'neutral' governance or policy advice tool, then it has to assume the inherent normativities well-entrenched in its DNA. This is where I can share the authors' critique that TA may not (enough) address its own normativities. Still, both conceptually and through its modes of operation (e.g. methods and concepts, publications, policy interventions), TA is intrinsically normative as it purports a different socio-technical order to $b e$; indeed, as TA practitioners purport a more inclusive and equitable science-society relationship than is presently the case and act on their commitments to improve technology in society, they engage with ethics in a broad sense (Lucivero, van Ouheusden, and AQ5 Delvenne forthcoming). However, the normative-ethical agenda of TA is rarely rendered explicit and actively reflected on within TA communities. Armin Grunwald, the Director of the German PTA, diagnosed the normative deficit of TA as early as 1999 but it seems that a substantial part of that diagnosis is still valid today. As a consequence, TA practitioners overlook a whole range of questions that have methodological, practical and political implications for TA and the broader context in which TA plays out. However, I disagree with that being the background for the authors' claim that RRI would be 'a next step of TA' or even a 'form of TA'. In the remainder of this short response, I will explain why I believe RRI is different from TA and why, rather than a critique of TA, RRI could instead lead to a travesty of TA, threatening the vitality and the uniqueness of TA institutions in the long-term.

RRI is the blunt expression of an oxymoron. As such, innovation cannot be responsible due to the inherently uncertain and disruptive process of creative destruction that characterizes innovation (Schumpeter 1942). Therefore, RRI reflects the need to reconcile a tension between the unconditional support of STI as strategic resources to generate growth and competitiveness and the acknowledgment that it is far from automatic that STI will meet the needs and concerns of citizens or contribute to an increase of their well-being. Two perspectives can be derived from this observation (Thoreau 2013) and related to TA practices. The first perspective revolves around the idea that RRI would 
be a response to what the German sociologist Beck (1992) calls 'organized irresponsibility', which designates the systemic denial of risks within modern cultural and industrial structures. Beck uses these terms to point at a contradiction between an emerging public awareness of technological risks produced by and within the social-institutional system on the one hand, and the lack of attribution of systemic risks to this system on the other (Mythen 2007). According to him, the advent of a 'risk society' is characterized by a shift in the power play between the production and distribution of 'social goods' (healthcare, employment, sustainability and wealth) and the production and distribution of 'social bads' (environmental pollution and contaminated food-stuffs). Progressively, and largely unconsciously, welfare state societies have drifted away their central focus on the positive acquisition of 'goods' towards a negative logic bound up with the avoidance of 'bads' (Mythen 2007, 798). To counterbalance the side effects of industrial and technological progress, following Hennen (1999), I have argued elsewhere (Delvenne 2011; Delvenne, Fallon, and Brunet 2011) that TA emerged as a practicable institutional response to real-world challenges that are hard to control, such as socio-technical uncertainties, controversies and public ambivalence about technology developments. These developments played out in the context of 'reflexive modernization' (Beck 1992; Beck, Giddens, and Lash 1994; Beck and Grande 2010) in which modern societies and institutions are thrown back on themselves. From that perspective, the addition of the wor(l)d 'responsible' next to 'innovation' reasserts the possibility of modulating the co-evolution of science and technology in society (Fisher, Mahajan, and Mitcham 2006; Rip 2006) and sustains the modernist fiction that the side effects of industrial modernity can be kept under control. Nevertheless, one can still argue that this is exactly what TA has been doing for the last five decades, so why would we need a new concept, if it turns out to be just old wine in new bottles?

This leads me to stress a second perspective from which to look at RRI as an oxymoron. It sheds light on the blatant absurdity of a figure of speech, which, to me resembles a diversionary tactic (Méheust 2009; Gutwirth and Christiaens 2015) for absorbing, rather than reconciling, an irreducible tension - how to justify unconditional support of STI while assuming the side effects of its developments - without putting it into politics, which is precisely the central aim of TA. Under that perspective, RRI results in an approach avoiding any true disturbance of the development of new innovations (Thoreau 2013). As van Oudheusden has convincingly argued, there is not much room for politics in RRI. The AQ6 approach 'largely ignores questions about the politics in deliberation (e.g. how actors craft RRI through strategic use of argument and other advantage-seeking techniques), as well as the politics of deliberation (e.g. how RRI privileges a process definition of democracy at the cost of participatory and representative perspectives). He adds that

AQ7 proponents of RRI typically present RRI along procedural lines rather than political ones; that is, they emphasize the importance of talk, deliberative argumentation, and due procedure without attending to questions of power, ends, and authority that play out in, and through, RRI processes. (Thoreau 2013, 3)

For Van Oudheusden (2014), the neglect or rejection of politics, understood as the constitution and contestation of power, is a common feature of both RRI and TA.

A crucial difference between TA and RRI, however, is that RRI posits innovation as a good in itself (Dodier 1993), meaning that it is a goal worth pursuing as such. The 
underlying logic is that it would be immoral to oppose or contest the development of innovations, especially when it is expected from them to fix a set of epochal crises and grand challenges (Tyfield 2012). To make sense of what makes that rationale 'responsible' to the tenants of the approach, it is heuristically illuminating to confront what they take as good in itself to what they implicitly consider as bad in itself (Goulet 2016), namely strong public dissent or resistance to the adoption or the development of new technologies. From a historical perspective, it is no surprise if at the EU level the development of RRI went hand in hand with the development of nanotechnologies (Thoreau 2013). At stake was the felt need to 'get it right from the very beginning' (Roco and Bainbridge 2005), in order to avoid the failure of the GMO moratorium and to eschew 'irrational' struggles resulting from misunderstandings and leading to impracticable policy decisions (Grunwald 2014).

Therefore, for innovation to be governable, RRI distributes responsibility to supposedly rational and autonomous individuals. By promoting the adoption of soft governance tools, like codes of conduct, RRI develops into a new form of governmentality (Thoreau 2013; Van Oudheusden 2014); that is, a strategy to intervene in science and technology to rationalize actions and control actors from a distance (Rose 1999; Foucault 2008 [1978]). RRI therefore reproduces the constant denial of the system of 'organized irresponsibility', which

manifests itself in [...] technically orientated legal procedures designed to satisfy rigorous causal proof of individual liability and guilt. This self-created dead end, in which culpability is passed off on to individuals and thus collectively denied, is maintained through political ideologies of industrial fatalism: faith in progress, dependence on rationality and the rule of expert opinion. (Elliott 2002, 297-298)

In other words, as RRI elevates innovation as a 'social good', at the same time, it diverts public and political attention from the 'social bads' induced by innovation. To ensure the rightful distribution of responsibility, RRI promotes the 'co-responsibility' of industrial and societal actors, implying both a transfer of responsibility at the level of individuals and a collective appeal to responsibility supported by public debate. However, by considering that 'upon everyone's shoulders rests a particular moral obligation to engage in the collective debate that shapes the context for collective decision making' (Von Schomberg 2007; Owen, Macnaghten, and Stilgoe 2012, 756), RRI's rationale moralizes publics, trivializes those who would not want to 'take their part' of responsibility, and ignores the more vulnerable individuals who lack the economic, political and cultural resources to engage in collective debate.

Under the spell of RRI, TA risks being reduced to a role of mere provider of ex-ante impact assessments. Von Schomberg (2011b) does not make any mystery of the future he envisions for TA:

In the context of European policy making, Technology Assessments (TA), ideally, have to merge with other types of impact assessments, as the success of major public policies increasingly depend on the anticipated impacts or the selected scientific and technological options.

In that ostensibly ideal future, 'the quest for positive or right impacts' eludes highly political questions (such as, for instance, whose right impacts? Positive for whom? Serving what interests? Towards what goals?), and forces TA institutions to shift their practices 
to fit with what RRI tenants take as emerging features of public policy. Such a shift may undermine the added value of TA knowledge, compared to foresight or other strategic intelligence bodies called upon to foresee and legitimate the possible outcomes of planned innovation activities.

This time is critical for TA institutions, struggling for survival in an epoch of scarce public resources. Following the money attached to RRI has a price that TA institutions should carefully, critically and reflexively consider before they pay. Just like the monster created by Frankenstein, RRI is here to stay and is taking a life of its own: $:^{5}$ TA professionals, practitioners and communities will have to experiment, not only in labs but also in the real-world of politics, with how they can and ought to cope with it.

\section{Notes}

1. For the sake of clarity, I want to mention that I am working in the field of science and technology studies (STS), with an active participation in several STS associations. At the same time, I have been engaged in technology assessment activities in the last 10 years (as part of $\mathrm{PhD}$, postdoctoral or collaborative research at the EU level, e.g. in the PACITA project). I thus also consider myself a TA practitioner and member of the TA community at large. Lastly, the research centre I am co-directing is an Associate Member of the European Parliamentary Technology Assessment (EPTA) network.

2. The terms 'responsible innovation' or 'responsible research and innovation' have a history stretching back 15 years or so and multiple roots in the United States and Europe (Owen, Macnaghten, and Stilgoe 2012, 751, Van Oudheusden 2014). However, it is in Europe, and especially at the European Commission policy level, that the terms gained the more visibility and traction (Owen, Macnaghten, and Stilgoe 2012). For this reason, and also because the Parliamentary Technology Assessment offices and networks are mostly located in Europe, this essay will take Europe as its primary focus.

3. PACITA was a four-year (2011-2015) EU-financed project under 7th Framework Programme aimed at increasing the capacity and enhancing the institutional foundation for knowledge-based policy-making on issues involving science, technology and innovation, mainly based upon the diversity of practices in Parliamentary Technology Assessment (PTA). See www.pacitaproject.eu.

4. Examples include the CIVISTI method, combining future-oriented discussions of national citizens panels and stakeholder and expert participation (www.civisti.org), or the World Wide Views method, which has been used at the European and global levels to organize citizens consultations on policy issues (www.wwviews.org).

5. While others are less certain as to whether RRI will indeed evolve at the policy level into a distinct let alone a lasting form (e.g. Rip 2016), such a state of affairs does not lessen in my mind potential concerns that RRI may nevertheless exert an undue influence on TA funding, TA practices, or both.

\section{Acknowledgements}

The author wants to express his gratitude to his colleagues Benedikt Rosskamp, François Thoreau and Michiel van Oudheusden for their constructive comments on preliminary versions of this essay.

\section{Disclosure statement}

AQ8 No potential conflict of interest was reported by the author. 


\section{Funding}

This work was supported by Fonds De La Recherche Scientifique - FNRS.

\section{Notes on contributor}

Pierre Delvenne, Research Associate of the Fund for Scientific Research (FNRS) and Associate Director of the SPIRAL Research Centre at the University of Liège, Belgium, where he coordinates the Research Unit in Science, Technology and Society.

\section{References}

AQ9 Beck, Ulrich. 1992. Risk Society: Towards a New Modernity. Vol. 17. Sage.

Beck, Ulrich, Anthony Giddens, and Scott Lash. 1994. Reflexive Modernization: Politics, Tradition

AQ10 and Aesthetics in the Modern Social Order. Stanford University Press.

375 Beck, Ulrich, and Edgar Grande. 2010. "Varieties of Second Modernity: The Cosmopolitan Turn in Social and Political Theory and Research." The British Journal of Sociology 61 (3): 409-443.

Cohen, Leonard. 1992. Anthem. The Future. Leonard Cohen Stranger Music, Inc (BMI).

Decker, M., and M. Ladikas. 2004. Bridges between Science, Society and Policy: Technology Assessment between Methods and Impacts. Berlin: Springer.

Delvenne, Pierre. 2011. Science, technologie et innovation sur le chemin de la réflexivité. Enjeux et dynamiques du Technology Assessment parlementaire. Louvain La Neuve: Academia Bruylant.

Delvenne, Pierre, Nathan Charlier, Benedikt Rosskamp, and Michiel van Oudheusden. 2015. "Deand Re-Institutionalizing Technology Assessment in Contemporary Knowledge-Based Economies." Technikfolgenabschätzung-Theorie und Praxis 24 (1): 20-29.

Delvenne, Pierre, Catherine Fallon, and Sébastien Brunet. 2011. "Parliamentary Technology Assessment Institutions as Indications of Reflexive Modernization." Technology in Society 33 (1): $36-43$.

Dodier, Nicolas. 1993. "Les appuis conventionnels de l'action: Eléments de pragmatique sociologique." Réseaux 11 (62): 63-85.

Elliott, Anthony. 2002. “Beck's Sociology of Risk: A Critical Assessment.” Sociology 36 (2): 293-315.

Fisher, Erik, Roop L. Mahajan, and Carl Mitcham. 2006. "Midstream Modulation of Technology: Governance from within." Bulletin of Science, Technology \& Society 26 (6): 485-496.

Foucault, Michel. 2008. The Birth of Biopolitics: Lectures at the Collège de France, 1978-1979.

AQ11 Springer.

Ganzevles, Jurgen, Rinie van Est, and Michael Nentwich. 2014. "Embracing Variety: Introducing the Inclusive Modelling of (Parliamentary) Technology Assessment." Journal of Responsible Innovation 1 (3): 292-313.

Goulet, Frédéric. 2016. "Faire science à part. Politiques d'inclusion sociale et recherche agronomique en Argentine." Diss., Université Paris-Est.

Grin, John, Henk Van de Graaf, and Robertus Hoppe. 1997. Technology Assessment through Interaction: A Guide. The Hague: Rathenau Institute.

Gross, Matthias, and Wolfgang Krohn. 2005. "Society as Experiment: Sociological Foundations for a Self-Experimental Society." History of the Human Sciences 18 (2): 63-86.

Grunwald, Armin. 1999. "Technology Assessment or Ethics of Technology? Reflections on Technology Development between Social Sciences and Philosophy." Ethical Perspectives-

AQ12 Katholieke Universiteit Leuven 6 (2): 170-182.

Grunwald, Armin. 2014. "Responsible Research and Innovation: An Emerging Issue in Research Policy Rooted in the Debate on Nanotechnology." In Responsibility in Nanotechnology

AQ13 Development, 191-205. Dordrecht: Springer.

Guston, David H., and Daniel Sarewitz. 2002. "Real-Time Technology Assessment." Technology in Society 24 (1): 93-109. 
Gutwirth, Serge, and Jenneke Christiaens. 2015. "Les sciences et leurs problèmes: la fraude scientifique, un moyen de diversion?" Revue interdisciplinaire d'études juridiques 73 (1): 21-49.

Hennen, Leonhard. 1999. "Participatory Technology Assessment: A Response to Technical Modernity?” Science and Public Policy 26 (5): 303-312.

Hennen, Leonhard, and Linda Nierling. "The Politics of Technology Assessment." Call for Papers, 3rd European Technology Assessment Conference, Cork, May 17-19, 2017. http://cork2017. technology-assessment.info/images/files/Call-for-Papers---The-politics-of-TA.pdf.

Horst, Maja. 2014. "On the Weakness of Strong Ties." Public Understanding of Science 23 (1): 4347.

Jasanoff, Sheila. 2011. Designs on Nature: Science and Democracy in Europe and the United States.

AQ14 Princeton University Press.

Joss, Simon. 2000. "Participation in Parliamentary Technology Assessment: From Theory to Practice." In Parliaments and Technology. The Development of Technology Assessment in Europe, edited by Norman J. Vig and Herbert Paschen, 325-362. Albany: SUNY Press.

Joss, Simon, and Sergio Bellucci. 2002. "Participatory Technology Assessment." In European

AQ15 Perspectives. London: Center for the Study of Democracy.

Klüver, Lars, Rasmus Øjvind Nielsen, and Marie Louise Jørgensen, eds. 2016. Policy-Oriented

AQ16 Technology Assessment Across Europe: Expanding Capacities. Springer.

Lucivero, Federica, Michiel van Ouheusden, and Pierre Delvenne. Forthcoming. "Making the

AQ17 Invisible Visible. Nomativities in Technology Assessment."

Méheust, Bertrand. 2009. "La politique de l'oxymore." Comment ceux qui nous gouvernent nous masquent la réalité du monde.

Miller, Clark A. 2008. "Civic Epistemologies: Constituting Knowledge and Order in Political Communities." Sociology Compass 2 (6): 1896-1919.

Mythen, Gabe. 2007. "Reappraising the Risk Society Thesis: Telescopic Sight or Myopic Vision?" Current Sociology 55 (6): 793-813.

Owen, Richard, Phil Macnaghten, and Jack Stilgoe. 2012. "Responsible Research and Innovation: From Science in Society to Science for Society, with Society." Science and Public Policy 39 (6): 751-760.

PACITA Manifesto. http://www.pacitaproject.eu/ta-manifesto/ (accessed 20 February 2017).

Rip, Arie. 2006. A Co-Evolutionary Approach to Reflexive Governance - and Its Ironies, edited by J.

AQ18 P. Voss, D. Bauknecht and R. Kemp. Cheltenham: Edward Elgar.

Rip, Arie. 2016. "The Clothes of the Emperor. An Essay on RRI in and around Brussels." Journal of Responsible Innovation 3 (3): 290-304.

Rip, Arie, Thomas J.Misa, and Johan Schot, eds. 1995. Managing Technology in Society. New York: Pinter Publishers.

Rip, Arie, and Harro van Lente. 2013. "Bridging the Gap between Innovation and ELSA: The TA Program in the Dutch Nano-R\&D Program NanoNed.” NanoEthics 7 (1): 7-16.

Roco, Mihail C., and William Sims Bainbridge. 2005. "Societal Implications of Nanoscience and Nanotechnology: Maximizing Human Benefit.” Journal of Nanoparticle Research 7 (1): 1-13.

Rose, Nikolas. 1999. Powers of Freedom: Reframing Political Thought. Cambridge: Cambridge University Press.

Schot, Johan, and Arie Rip. 1997. "The Past and Future of Constructive Technology Assessment." Technological Forecasting and Social Change 54 (2-3): 251-268.

AQ19 Schumpeter, Joseph. 1942. "Creative Destruction." Capitalism, Socialism and Democracy 825.

Thoreau, François. 2013. "Embarquement immédiat pour les nanotechnologies responsables. Comment poser et re-poser la question de la réflexivité?" $\mathrm{PhD}$ thesis, Université de Liège.

Tyfield, David. 2012. "A Cultural Political Economy of Research and Innovation in an Age of Crisis." Minerva 50 (2): 149-167.

Van Eijndhoven, Josee CM. 1997. “Technology Assessment: Product or Process?” Technological Forecasting and Social Change 54 (2-3): 269-286.

Van Lente, Harro, Tsjalling Swierstra, and Pierre-Benoît Joly. 2017. "Responsible Innovation as a 450 AQ20 Critique of Technology Assessment." Journal of Responsible Innovation. 
Van Oudheusden, Michiel. 2014. "Where are the Politics in Responsible Innovation? European Governance, Technology Assessments, and beyond." Journal of Responsible Innovation 1 (1): $67-86$.

Van Oudheusden, Michiel, Nathan Charlier, Benedikt Rosskamp, and Pierre Delvenne. 2015. "Broadening, Deepening, and Governing Innovation: Flemish Technology Assessment in Historical and Socio-Political Perspective." Research Policy 44 (10): 1877-1886.

Vig, Norman J., and Herbert Paschen. 2000. Parliaments and Technology: The Development of Technology Assessment in Europe. Albany: SUNY Press.

Von Schomberg, René. 2007. From the Ethics of Technology towards an Ethics of Knowledge Policy \& Knowledge Assessment. Brussels: European Commission.

Von Schomberg, René. 2011a. Towards Responsible Research and Innovation in the Information and Communication Technologies and Security Technologies Fields. Brussels: European Commission. https://philpapers.org/archive/VONTRR.pdf (accessed 20 February 2017).

Von Schomberg, René. 2011b. "Prospects for Technology Assessment in a Framework of Responsible Research and Innovation." In Technikfolgen abscha "tzen lehren. Bildungspotenziale transdisziplina "rer Methoden, edited by M. Dusseldorp and R. Beecroft, 465 AQ21 39-61. Springer.

Wilsdon, James, Jack Stilgoe, and Brian Wynne. 2005. The Public Value of Science: Or How to AQ22 Ensure that Science Really Matters. Demos.

AQ23 Winner, Langdon. 1980. “Do Artifacts have Politics?” Daedalus, 121-136. 